\title{
The Service Quality and Its Influence in Expectations and Satisfaction Levels of the Consumers of Educational Services in the Business Schools
}

\author{
Jorge Isaac Álvarez Rateike, Enrico Joaquín Ahrens Solera \\ FUNDESEM Business School, Alicante, Spain
}

\begin{abstract}
Nowadays, quality has become highly important, and many decisions regarding consumption are based on the degree of satisfaction obtained when experiencing products and services supplied by a business. For this reason, it is essential for the supply of such products (in the case of this research, educational services) not only to be of quality, but also to be capable of meeting consumer's expectations. For that reason, the authors want to explain how the quality of service and the expectations has a direct influence in the satisfaction levels of the consumers. Based on the above, a model is presented that attempts to explain how the various elements that are involved in the process of expectation disconfirmation affect consumer-based decisions. To contrast the model empirically, information was gathered from students of a Business School located in Alicante, Spain. To achieve this, a measuring instrument was developed and validated, with which 264 valid questionnaires were gathered. Statistical analysis was carried out using SPSS and EQS. The statistical method used to analyze data was the Structural Equation Modeling (SEM). The result obtained is the role and the direct effect that expectations and the quality of educational services play in the satisfaction levels obtained and in client loyalty.
\end{abstract}

Keywords: satisfaction, expectations, service quality, loyalty

\section{Introduction}

Offering quality products and services is essential for convincing consumers today, as they are exposed to a wide range of products and services and tend to be much stricter when making consumption-based decisions. For this reason, particular care needs to be taken over aspects such as quality, expectations and the level of satisfaction obtained when experiencing the product or service, as to a large extent the level of loyalty achieved with the consumer will depend on this.

\section{Theory and Hypothesis}

\section{Total Quality and Its Definition}

Total quality is a relatively new term in the Western world, but has long been used by Eastern cultures. Quality means not only a complex model that organisations must now adapt to if they want to have a

Jorge Isaac Álvarez Rateike, Ph.D. candidate, Research Department, FUNDESEM Business School. Enrico Joaquín Ahrens Solera, Ph.D. candidate, International Business, FUNDESEM Business School. Correspondence concerning this article should be addressed to Jorge Isaac Álvarez Rateike, FUNDESEM Business School, Calle Deportistas Hermanos Torres, 4. 03016, Alicante, Spain. E-mail: jalvarez@fundesem.es. 
competitive advantage on globalised markets, it is also a requirement for survival faced with consumers who are increasingly demanding when making consumption-based decisions. Authors such as Oxenfeld (1950, p. 314) defined quality as "all attributes of a product which yield consumer satisfaction". Zeithaml (1988, p. 3) defined it as "the consumer's judgement about a product's overall excellence or superiority”. Deming (1989, p. 3) defined it as "offering products and services at low cost that satisfy customers; it involves a commitment to innovation and continuous improvement". Steenkamp (1990, p. 311) defined it as "convenience of use covering the client's needs”. Galgano (1993, p. 33) went further and defines quality as "total customer satisfaction”. For Reed, Lemak, and Montgomery (1996, p. 178), quality means "producing goods and/or services according to specifications that satisfy the needs and expectations of customers”.

\section{Total Quality Management}

In recent years, total quality management is one of the issues that has aroused most interest and been the subject of most research in the business world. The origins of this interest lie in the processes of economic globalisation, market competition growth levels, the spread of innovation (combined with major advances in technology) and a movement of consumers of products and services who demand much higher levels of quality in their purchasing behaviour. Combined with the notion of low quality system management levels in businesses, this has resulted in a new paradigm of total quality management. Due to this, and given the inability of current systems to respond to the challenges of globalisation, an effective quality management system is needed that helps to improve and promote consumer satisfaction levels. Taking all the above into account, it is clear that total quality management systems do exist, such as the "European Model of Total Quality Management”, developed by the European Foundation for Quality Management (EFQM) and the model based on ISO standards.

\section{Quality Applied to Education}

For decades, quality has been a very attractive concept in educational service provision. Due to the way that both the study and the application of this concept continues to evolve, it is now considered an important factor differentiating services provided by both public and private institutions. One example of this is the studies conducted by authors such as Lindhal (1995), who proposed a series of criteria to measure the quality of higher education services (degree-level studies). Lindhal advocates taking more relevant aspects than those traditionally used into account, such as (1) observing students when they rate service quality; (2) overall satisfaction with the education services received; (3) achieving the learning and academic performance objectives set; (4) the intention of recommending the education service; (5) levels of proficiency in professional examinations; (6) admissions to various higher education institutions; and (7) student opinion surveys. Another example is the studies conducted by Bogue and Saunders (1992), who proposed creating a quality system and a philosophy based on it to create and implement a philosophy based on quality that will affect the whole organisation and involve everyone in it. For this reason, learning centres today need information on the level of quality of services provided, particularly in highly competitive markets where education services have even become a mass-market product. This information can and should be used to determine weak points in the institution's education services proposal, so it can be modified and adapted when necessary. However, according to Freed and Klugman (1997), one of the difficulties lies in how complex it is to measure education service quality. Other researchers have shown the relationship between student satisfaction levels and the environment, which is formed by the views of the teaching staff, and the conclusion is that the environment can 
have an influence on students' levels of satisfaction.

Various research works emphasise how important satisfaction can be in conceptualising quality in education services, however, marketing gurus such as Kotler (1982) and Kotler and Fox (1985) stated that achieving satisfaction in various markets does not mean that an education institution should compromise its mission and programmes merely to attract students, but rather should pay more attention to students' long-term needs and above all to the prevailing needs in the community and/or society where the institution is located. These authors also maintain that an institution providing education services may have more than one objective and must therefore consider not only students' needs, but also their tastes and preferences, while also maintaining its academic reputation, together with the institution's various other objectives and commitments (Kotler \& Fox, 1985). As a result of the above, quality is now a crucial issue in education services and a key element for their growth, focusing to a large extent on maintaining and improving education and learning levels. It should also be considered that educational institutions involve highly complex technical, scientific, and social systems, which all have an influence on students. The objective or main goal, therefore, is to enable people to make the right decisions about education and to be consistent when assessing quality by ensuring that it is properly managed.

\section{Service Quality}

Nowadays, services represent a sector of great importance and growth in national economies, which in some situations can account for over $60 \%$ of GDP. To speak about a service is to speak about an element with unique characteristics differentiating it from a manufactured product. It is important to make clear that a service is not a product as each has distinguishing characteristics making them unique. Authors such as Parasuraman, Zeithaml, and Berry (1985) have from the outset specified the big differences between a product and a service which are grouped into four: inseparability (Grönroos, 1984), intangibility (Lovelock, 1983), heterogeneity (Parasuraman et al., 1985), not storable (Rushton \& Carson, 1989).

The concept of service quality can be defined as "a global opinion, or attitude, which is relative to the superiority of the service" or as "the degree and direction of the discrepancies between the perceptions and the expectations of the consumer regarding the service” (Parasuraman, Zeithaml, \& Berry, 1988, p. 16). Other authors such as Santiago (1999, p. 42) define the concept as "the perception the client has regarding the correspondence between performance and expectations related to the set of elements, principal and secondary, quantitative and qualitative, of a main service”.

Table 1

The Discrepancies or Gaps of the Parasuraman, Zeithaml and Berry Model (Adapted From Calabuig, 2005)

\begin{tabular}{ll}
\hline Discrepancy & Definition \\
\hline GAP 1 & The expectations and perceptions of consumers and the directors of the company. \\
GAP 2 & The perception of the directors of the company of the expectations of clients and quality levels. \\
GAP 3 & The discrepancy between the actual service and what information the consumer is given. \\
GAP 4 & The discrepancies between the service promised and that delivered to the consumer. \\
GAP 5 & The discrepancy between the consumer's expectations and the resultant perceptions of the experience of use. \\
\hline
\end{tabular}

On the other hand, and throughout the study of the development of the concept of service quality, there have been many approaches. Today, people can speak about two different approaches to this topic based on the available literature, the first being the Nordic approach, led by Grönroos (1982) and called "the image model" 
based on two dimensions - technical (the design of the service) and functional (the operational capacity of the service); and the second being the American approach—led by Parasuraman, Zeithaml, and Berry $(1985,1988)$ and their "discrepancies model" based on five "gaps" (see Table 1), both models having high validity and applicability today.

Service quality has been converted into a useful tool and, in its turn, an imperative for the differentiation of services from the competition, especially in a globalized world where consumers are increasingly more demanding and informed with regard to products/services on offer.

\section{Consumer Expectations}

At the present time, consumer expectations have acquired great relevance for research within the marketing area as they occupy a central position in the discussion of the two most commonly used concepts: service quality and consumer satisfaction (San Martín, 2005). Attempting to create a general definition of the concept of expectations, authors such as Parasuraman et al. (1988, p. 17) state that expectations can be defined as "the desires or needs of consumers, that is to say, what they feel must be delivered by a service provider against that which could be offered". Following on from this, there are many comparison standards, which we will state and explain in more detail below. These are: (1) predictive expectations; (2) standards based on experiences; (3) cognitive scheme; (4) standards based on equity; (5) the consumer's wants; and (6) ideal expectations.

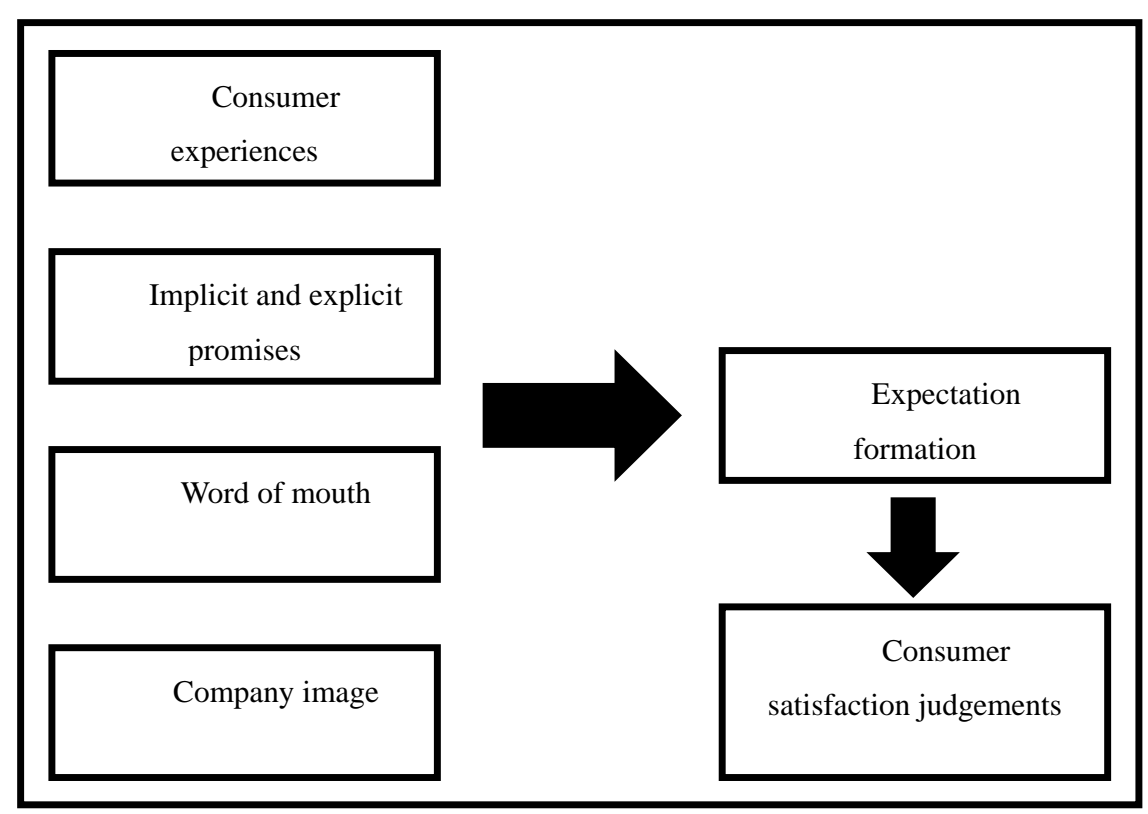

Figure 1. Influence in the formation of consumer expectations (Source: author's own.).

Following on from the above, and reaffirming that predictive expectations are of the type most used in so-called satisfaction judgements, it is also important to mention the sources contributing to their formation (San Martín, 2005) among which are the consumer's experience (direct and indirect contact with the service); according to Patterson and Johnson (1995), the greater the experience of use is, the greater and stronger the expectations generated will be), the implicit promises (signals attached to, or part of, the product and/or service) and the explicit promises (referring to ratings, which may be personal or impersonal, of the company regarding 
a specific product and/or service), word of mouth, according to San Martín (2005, p. 146) this is the oral message that a client, or any person, gives to another on the credibility, reliability and the services of an organization) and the company image (the general attitude of a consumer, or group of consumers, towards the company) (see Figure 1).

\section{Service Quality and Its Relationship to Consumer Expectations: The Disconfirmation Paradigm}

Civera (2008) stated that there are many authors who support the disconfirmation paradigm theory, which is encompassed in assessing the quality of service perceived as an imbalance between expectations and perceptions of the achieved results. Grönroos (1994) stated that the perceived quality of a service depends on the comparison of the expected service with the perceived service and, because of this, it is the result of a continuous evaluation process. Without established parameters for measurement, the clients' perceptions are used in order to assess service quality (Parasuraman et al., 1988), the latter being understood as "the shortcomings relating to the service received by consumers” (Civera, 2008, p. 11).

Service quality, therefore, is understood as an attitude, which is related to, but not equivalent to, satisfaction and is the result of comparisons made between expectations and actual results (Grönroos, 1984; Parasuraman et al., 1991). These expectations can be formed by taking into account past experiences, word of mouth, clients' wants, expert opinions, previous exposure to the competition's services, etc. (Brown \& Swartz, 1989; Parasuraman et al., 1985).

Following on from this, and according to Parasuraman et al. (1988, p. 14), the clients who actually assess the quality of a service, do this by comparing what they expect or want with what they actually receive, and it starts "from the discrepancies between the consumers' perceptions of the services offered by a company in particular and their expectations regarding the offer from companies of such services” which results, as stated before, in a comparison between the initial expectations and the reality received. Due to the latter, the final outcome of this discrepancy is according to the "magnitude and direction of the adjustment between the expected service and the perceived service” (Parasuraman et al., 1988, p. 17).

It is necessary to mention that the perceptions are linked to the beliefs which a client has in the service received. As a result of this, "the judgements of high or low service quality depend on how the consumers perceive the current outcome of the service in the context of what they expected" (Parasuraman et al., 1985, p. 46). In conclusion, it can say that a client may perceive a service as being a quality service when this exceeds their initial expectations, or at least equates with them, otherwise it will be classed as a service of poor quality when their expectations are not fulfilled.

\section{Consumer Satisfaction and Its Definition}

According to authors such as Moliner, Berenguer, and Gil (2001), consumer satisfaction has been widely studied in recent years, but interest in measuring this satisfaction scientifically is very recent (Bello, Polo, \& Vázquez, 1999). Many authors have stressed the importance of reaching an agreement on the definition of the concept of consumer satisfaction (Peterson \& Wilson, 1992; Oliver, 1997; Giese \& Cote, 2000) and many authors and works of research have tried to define this concept, and the most representative definitions of the concept of consumer satisfaction include the following: Howard and Sheth (1969, p. 145) stated that "satisfaction is the buyer's cognitive state of being adequately or inadequately rewarded for the sacrifice he has undergone"; Day (1977a, p. 154) stated that "satisfaction is a conscious assessment or judgement by a consumer about the goodness of a company's product or service, or about adapting that product or business to 
his use or purpose"; Oliver (1981, p. 27) stated that "satisfaction is an assessment of the intrinsic surprise referring to the experience of purchasing and/or consuming a product. It is a global psychological state resulting from the difference between the emotion resulting from disconfirmed expectations and prior beliefs about the consumer experience"; Giese and Cote (2000, p. 3) stated that "satisfaction is a summary affective response of varying intensity, with a time-specific point of determination and limited duration, directed toward focal aspects of product acquisition and/or consumption”.

\section{Satisfaction Formation}

It is important to clarify that the consumer satisfaction formation process is supported by what is known as the disconfirmation paradigm (Wirtz, Mattila, \& Tan, 2001). According to Oliver (1980), in this paradigm, consumer satisfaction is determined by the difference between the perceptions of the so-called "performance" of a specific product or service and the consumer's expectations before making the purchase and consuming the product or service in question (see Figure 2). The disconfirmation paradigm, according to Oliver, is the result of the merging of various theories based on cognitive judgements and emotional responses. One of these theories is known as the disconfirmation theory, which is based on the "expectation disconfirmation model". In general terms, this model attempts to explain that once consumers have made a purchase and consume the product and/or service, they will make comparisons with their prior expectations, and as a result positive disconfirmation occurs when "performance" exceeds prior expectations and negative disconfirmation occurs when the results of the assessment made by consumers do not reach prior levels of expectation. Neither confirmation nor disconfirmation occurs when expectations are simply met (Howard \& Sheth, 1969; Cohen \& Houston, 1972; Oliver, 1980). This means that satisfaction occurs when there is positive disconfirmation (confirmation of expectations), whereas dissatisfaction occurs if there is negative disconfirmation. It can therefore be concluded that according to the above, disconfirmation predicts that satisfaction levels increase with "performance" and drop with expectations, so both variables are the basis for this paradigm and the combination of the two is what determines a consumer's degree of satisfaction.

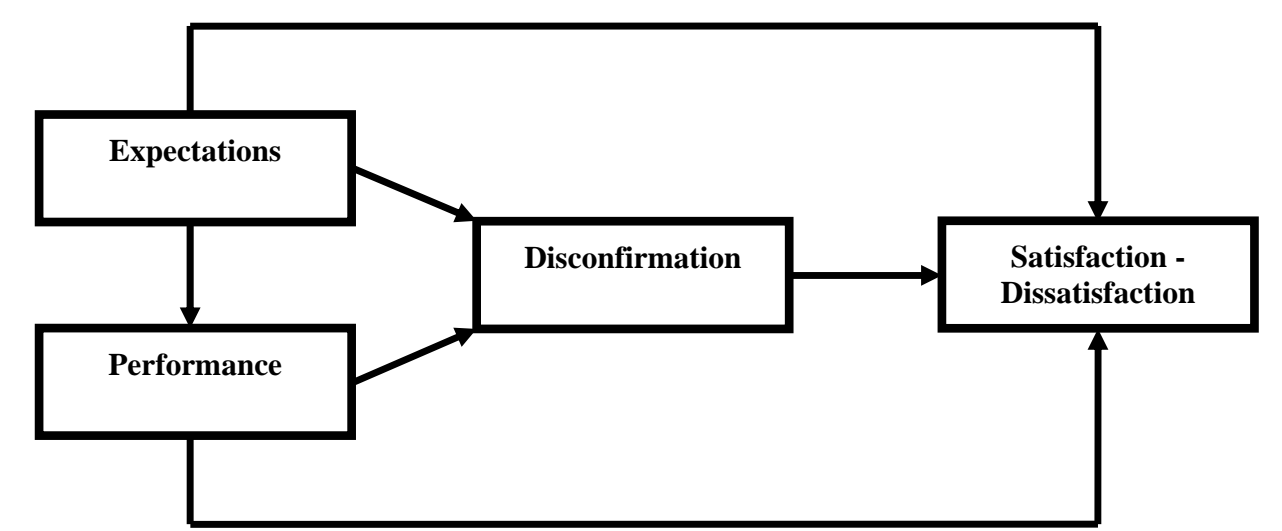

Figure 2. Effects of consumer expectation disconfirmation (Source: Moliner, Berenguer, \& Gil, 2001, p. 168).

Finally, there are various consequences resulting from the consumer satisfaction process, which can be classed according to the area that they affect or influence at a consumer or business level. The consumer level involves variables such as attitudes and intentions, as well as concepts such as loyalty to the organisation (Thomas, 2001; Petrick \& Sirakaya, 2004), word of mouth (Szymanski \& Henard, 2001; Yoon \& Uysal, 2005) and complaints (Singh \& Howell, 1985) in the event of dissatisfaction. At the business level, the consequences 
of consumer satisfaction are reflected in profit levels, market share, sales figures, and so on, all of which is the result of client loyalty.

\section{Research Design}

\section{Formulating Hypotheses}

Having analysed the existing literature on service quality and consumer satisfaction, the following stage of this research is to formulate the hypotheses that will be subject to study, justification and contrast.

Expectations are a key element and have been widely studied in terms of their relationship and their influence on consumer satisfaction, as it is a basic element in what is known as the disconfirmation paradigm and is a measuring standard that is widely used in both theoretical and practical contributions (Clow, Kurtz, \& Ozment, 1998; Taylor \& Burns, 1999; Moliner et al., 2001). According to authors such as Day (1975) and Swan and Trawick (1979), expectations are an assessment that consumers make about what will happen after a purchasing experience and can be defined as "a pre-purchase estimation of the extent to which the desired benefits of the product will be achieved or of the level of performance that said product will achieve" (Moliner et al., 2001). Expectations feed on people's experiences, an individual's learning, which is based on one's own experiences, helps to form more stable and accurate expectations, which helps to make much better purchasing decisions and which in turn have a positive influence on one's satisfaction levels. According to research carried out, expectations have a direct influence on consumer satisfaction/dissatisfaction levels (Olson \& Dover, 1976; Olander, 1977; Day, 1977a; LaTour \& Peat, 1979; Oliver, 1980, 1981; Swan \& Trawick, 1981). Work carried out by Oliver (1980) even states that a high level of expectation increases an individual's satisfaction, regardless of the positive or negative nature of the disconfirmation. Therefore, and based on the above, the following research hypotheses are proposed:

H1: Expectations have a significant influence on the expectation disconfirmation process.

H2: Consumer expectations have a significant influence on consumer satisfaction levels.

Furthermore, according to the literature consulted, satisfaction has its origin in two suppositions, one of which is performance, which has a direct influence on satisfaction (Engel, Kollat, \& Blackwell, 1968; Howard \& Sheth, 1969; Miller, 1977). This can be defined as "an individual's perception of an event experienced in relation to one's obligation in a transaction, and is considered a standard method of assessment" (Deighton, 1992, p. 363). According to some studies, performance is very important and influences the expectation disconfirmation model (Moliner et al., 2001) and consumer satisfaction (Cohen \& Houston, 1972; LaTour \& Peat, 1979; Oliver, 1980; Yi, 1993), as this is used as a basis for measuring levels of satisfaction reached by an individual when in contact with a particular product or service. Therefore, and based on the above, the following research hypotheses are proposed:

H3: Performance has a significant influence on the expectation disconfirmation process.

H4: Performance has a significant influence on consumer satisfaction levels.

Quality is also a direct determinant of satisfaction levels which an individual has when experiencing a particular product or service. Alves and Raposo (2004) conclude in their study that for educational products and services, satisfaction is influenced not only by perceived value and expectations, but also by the image and the perceived quality of the product or service (López, Fernández, \& Mariel, 2005). There are also studies that attempt to explain the causal relationship between service quality and consumer satisfaction, stating that quality is a direct antecedent of satisfaction. Authors proposing this postulate include Parasuraman, Zeithaml, and 
Berry (1985, 1988); Cronin and Taylor (1992); Oliver (1994); Rust and Oliver (1994); Brady and Robertson (2001); Caruana (2002); Sanzo, Del Rio, Iglesias, and Vazquez (2003); Setó (2003); Lee, Graefe, and Burns (2004); Petrick (2004b). Therefore, and based on the above, the following research hypothesis is proposed:

H5: Service quality has a significant influence on consumer satisfaction levels.

Based on the hypotheses formed above, the following theoretical model is proposed, which shall be contrasted in the statistical analysis (see Figure 3):

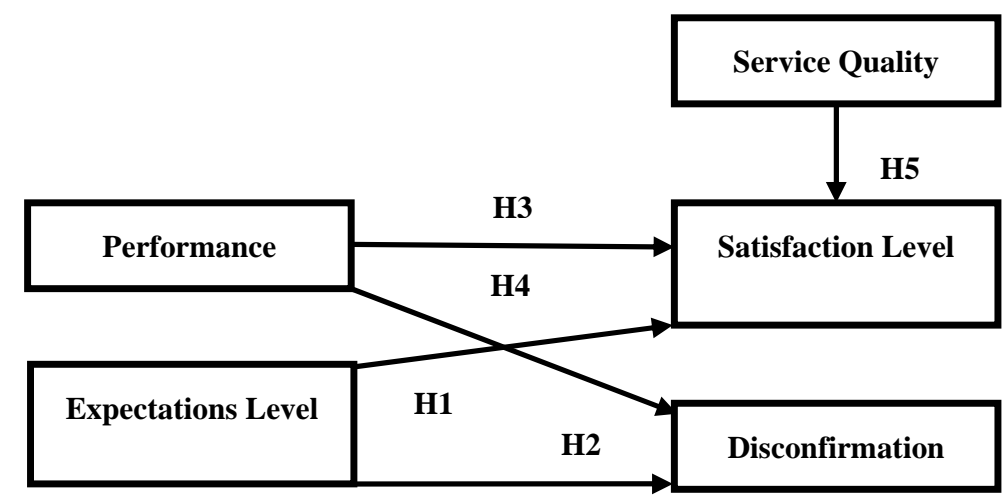

Figure 3. Theoretical model proposed (Source: author's own).

\section{Target Population and Sources of Information}

With regard to the process of gathering data to carry out this research, an instrument or questionnaire was produced containing 13 items with a five-point Likert-type scale for the satisfaction component; three items with a five-point Likert-type scale for expectations; three items with a five-point Likert-type scale for performance, and one item with a five-point Likert-type scale for quality. The population studied was defined as residents aged 18 to 70 years enrolled in a business school. The instrument designed was available in Spanish and was administered randomly with students from this school in the Spanish city of Alicante between March 7 and 28, 2011. In total, 264 surveys were administered. The data obtained were analysed with statistical techniques using EQS (v. 6.1) and SPSS (v. 15) software. The results of this analysis are presented below.

\section{Research Method}

\section{Descriptive Analysis}

The first objective is to produce a descriptive analysis of the indicators that make up the latent variables that will be used in subsequent statistical analyses. At this stage, the average performance of indicators is analysed. These indicators are also related to socio-demographic variables such as sex and age. Table 2 shows the mean for each variable included in the initial instrument, $t$-statistics of the contrast of means between sexes and the Pearson correlation coefficient to analyse the relationship between these items and the age of those surveyed.

From the results show in Table 2, the most positively valued aspects are overall perceived quality and most of the items relating to satisfaction, except for those relating to the job bank and value for money, which are explained as a result of the prevailing economic circumstance in Spain that weakens the economy's purchasing power and job-creation capability. The table also analyses the relationship between the indicators used in the instrument and sex, from this it can be stated that the sex of the person surveyed does not have much of an effect, given that only one of the 20 indicators used have significant differences. With regard to the 
variable of age, it does have a significant effect on the study variables, with 12 of the 20 affected. One aspect to highlight is that performance and expectations are not affected by age or sex.

Table 2

Descriptive Analysis (Author's Own Calculation)

\begin{tabular}{lllll}
\hline Variable & Description & Overall mean & $T$-statistic (sex) & Correlation coeff. (age) \\
\hline Perf1 & Image of the business & 3.61 & -0.082 & -0.032 \\
Perf2 & Image of products and services & 3.78 & -0.043 & 0.000 \\
Perf3 & Advertising & 3.89 & -0.001 & 0.004 \\
Cal & Overall perceived quality & 3.92 & 0.039 & 0.118 \\
Sat1 & Satisfaction-Installations & 3.62 & 0.065 & 0.099 \\
Sat2 & Satisfaction-Cafeteria & 3.67 & -0.060 & $0.125^{*}$ \\
Sat3 & Satisfaction-Library & 3.23 & 0.079 & $0.190^{* *}$ \\
Sat4 & Satisfaction-Reprographics & 3.44 & $0.187^{* *}$ & $0.162^{* *}$ \\
Sat5 & Satisfaction-ICTs & 3.30 & 0.100 & $0.129^{*}$ \\
Sat6 & Satisfaction-Customer service & 3.76 & 0.030 & $0.180^{* *}$ \\
Sat7 & Satisfaction-Quality of programmes & 3.27 & 0.045 & $0.168^{* *}$ \\
Sat8 & Satisfaction-Quality of teachers & 3.43 & 0.057 & $0.165^{* *}$ \\
Sat9 & Satisfaction-Reputation of school & 3.37 & 0.066 & $0.125^{*}$ \\
Sat10 & Satisfaction-Job banks & 2.69 & 0.000 & $0.313^{* *}$ \\
Sat11 & Satisfaction-Languages & 3.18 & -0.003 & $0.179^{* *}$ \\
Sat12 & Satisfaction-Value for money & 2.96 & 0.010 & $0.301^{* *}$ \\
Sat13 & Satisfaction-Internationalisation & 3.29 & -0.070 & $0.169^{* *}$ \\
Exp1 & Expectations as a basis for comparison & 3.99 & 0.008 & 0.019 \\
Exp2 & Importance of expectations being met & 4.17 & -0.042 & 0.038 \\
Exp3 & Expectations vs. satisfaction & 4.15 & 0.040 & 0.041 \\
\hline Notes. ${ }^{*} p<$ 0.05; $p<0.1$. & & & \\
& & & & \\
\end{tabular}

\section{Reliability and Validity of the Measuring Instrument}

Once the exploratory analysis of the variables measured had been completed, the manifest and latent variables were analysed, using a covariance model. However, before the structural analysis, the psychometric properties of the measuring instrument were assessed (Anderson \& Gerbing, 1988). The instrument was assessed for reliability and validity following a series of steps. A confirmatory factorial analysis was carried out on the factors with the measurement scales described above (expectations, satisfaction, quality, and performance), using the maximum likelihood method. Items with factor loadings that were not significant or below 0.6 were eliminated, ensuring good representation and contributing to the convergent validity of the instrument (Bagozzi \& Baumgartner, 1994; Bagozzi \& Yi, 1998). Table 3 shows the final composition of the instrument after this stage. All the model's measures of fit show reasonably good scores, close to 0.80 , which is considered acceptable (Lévy \& Varela, 2003): BBNFI $=0.732 ; B B N N F I=0.735 ; C F I=0.764$. The measurements of the residuals between matrices as observed and reproduced with regard to the population (RMSEA) is 0.140 and is therefore considered acceptable (Bollen, 1989). These three measures support the idea that the model's fit is acceptable. Because the model of measurement has a reasonably good fit and almost all the indicator's factor loadings are significant and greater than 0.6 , it can be concluded that the instrument has convergent validity.

With regard to reliability (see Table 3), all the Cronbach's $\alpha$ scores (Cronbach, 1951) are above the 
recommended value of 0.7 (Churchill, 1979; Nunnally, 1978). Given the limitations inherent to this first measurement, the composite reliability index and the average variance extracted (AVE) were also calculated. With regard to the variance extracted index (see Table 2), all the values are above the recommended value of 0.7 (Fornell \& Larcker, 1981). The AVE has values above or close to 0.5, the value recommended by Fornell and Larcker (1981). Joint consideration of these three indicators shows that the instrument is reliable. Finally, the confidence interval test (Anderson \& Gerbing, 1988) is within the range that is less than one, and as such the discriminant validity of the scales measured can be determined (see Table 4).

Table 3

Measuring Instrument: Reliability and Convergent Validity (Author's Own Calculation)

\begin{tabular}{|c|c|c|c|c|c|c|c|}
\hline Latent variable & Indicator & $\begin{array}{l}\text { Standardized } \\
\text { load }\end{array}$ & $T$-value & Cronbach's alpha & $\begin{array}{l}\text { Composite reliability } \\
\text { index }\end{array}$ & $\begin{array}{l}\text { Average } \\
\text { extracted }\end{array}$ & variance \\
\hline \multirow{3}{*}{$\begin{array}{l}\text { F1. } \\
\text { Performance }\end{array}$} & Perf1 & 0.643 & 10.446 & \multirow{19}{*}{0.906} & \multirow{3}{*}{0.8537} & \multirow{3}{*}{\multicolumn{2}{|c|}{0.665}} \\
\hline & Perf2 & 0.872 & 5.045 & & & & \\
\hline & Perf3 & 0.906 & 3.695 & & & & \\
\hline \multirow{13}{*}{$\begin{array}{l}\text { F2. } \\
\text { Satisfaction }\end{array}$} & Sat1 & 0.617 & 10.996 & & \multirow{13}{*}{0.9147} & \multirow{13}{*}{0.461} & \\
\hline & Sat2 & 0.545 & 11.144 & & & & \\
\hline & Sat3 & 0.527 & 11.173 & & & & \\
\hline & Sat4 & 0.601 & 11.034 & & & & \\
\hline & Sat5 & 0.476 & 11.244 & & & & \\
\hline & Sat6 & 0.643 & 10.927 & & & & \\
\hline & Sat7 & 0.862 & 9.237 & & & & \\
\hline & Sat8 & 0.849 & 9.478 & & & & \\
\hline & Sat9 & 0.807 & 10.033 & & & & \\
\hline & Sat10 & 0.640 & 10.938 & & & & \\
\hline & Sat11 & 0.581 & 11.078 & & & & \\
\hline & Sat12 & 0.856 & 9.352 & & & & \\
\hline & Sat13 & 0.664 & 10.863 & & & & \\
\hline \multirow{3}{*}{$\begin{array}{l}\text { F3. } \\
\text { Expectations }\end{array}$} & Exp1 & 0.824 & 9.358 & & \multirow{3}{*}{0.9156} & \multirow{3}{*}{\multicolumn{2}{|c|}{0.784}} \\
\hline & Exp2 & 0.943 & 4.006 & & & & \\
\hline & Exp3 & 0.885 & 7.300 & & & & \\
\hline
\end{tabular}

Notes. Chi-square $=3,505.849$ (171 gl; $p<0.01) ; B B N F I=0.732 ; B B N N F I=0.735 ; C F I=0.764 ;$ RMSEA = 0.140; Cronbach's $\alpha$ $=0.906$

Table 4

Confidence Interval Test (Author's Own Calculation)

\begin{tabular}{ll}
\hline Indicator & Interval \\
\hline Perf1 & {$[0.480 ; 0.700]$} \\
Perf2 & {$[0.140 ; 0.320]$} \\
Perf3 & {$[0.070 ; 0.230]$} \\
Sat1 & {$[0.410 ; 0.590]$} \\
Sat2 & {$[0.540 ; 0.780]$} \\
Sat3 & {$[0.530 ; 0.770]$} \\
Sat4 & {$[0.590 ; 0.850]$} \\
Sat5 & {$[0.750 ; 1.070]$} \\
Sat6 & {$[0.570 ; 0.830]$} \\
Sat7 & {$[0.330 ; 0.510]$} \\
Sat8 & {$[0.230 ; 0.350]$} \\
\hline
\end{tabular}


(Table 4 continued)

\begin{tabular}{ll}
\hline Indicator & Interval \\
\hline Sat9 & {$[0.270 ; 0.410]$} \\
Sat10 & {$[0.700 ; 1.020]$} \\
Sat11 & {$[0.450 ; 0.650]$} \\
Sat12 & {$[0.240 ; 0.380]$} \\
Sat13 & {$[0.450 ; 0.650]$} \\
Exp1 & {$[0.190 ; 0.290]$} \\
Exp2 & {$[0.050 ; 0.170]$} \\
Exp3 & {$[0.150 ; 0.270]$} \\
\hline
\end{tabular}

\section{Hypothesis Contrast}

Once the psychometric properties of the measuring instrument have been evaluated, the structural model was estimated, using the maximum likelihood method in the EQS 6.21 software (Bentler, 1989).

As shown in Table 5, the relationships in the theoretical model originally proposed were significant. In turn, we can see that the adjustment of the structural model is better than for the measurement model as indicated by the adjustment rates: $B N N F I=0.789 ; B B N N F I=0.762 ; C F I=0.781 ; R M E S E A=0.185$ or Chi-square $=3,205.325$ (152 df, $p<0.01$ ). These results suggest that the proposed and contrasted model can serve as a basis for analyzing the relationship between different factors that make the consumer satisfaction in educational services.

Table 5

Hypothesis Contrast (Author's Own Calculation)

\begin{tabular}{lll}
\hline Hypothesis & Standardized load & $T$-value \\
\hline H1: Expectations $>(+)$ Disconfirmation & 0.719 & $7.451^{* *}$ \\
H2: Expectations $>(+)$ Satisfaction & 0.729 & $8.179^{* *}$ \\
H3: Performance $>(+)$ Disconfirmation & 0.781 & $7.641^{* *}$ \\
H4: Performance $>(+)$ Satisfaction & 0.793 & $8.632^{* *}$ \\
H5: Service quality $>(+)$ Satisfaction & 0.745 & $7.952^{* *}$ \\
\hline
\end{tabular}

Notes. Chi-square = 3,205.325 (152 df; $p<0.01) ; B B N F I=0.789 ; B B N N F I=0.762 ; C F I=0.781 ;$ RMSEA $=0.185 .{ }^{* * *} p<0.01 ;{ }^{*}$ $p<0.05$.

\section{Correction Model}

Figure 4 shows the final and confirmed theoretical model.

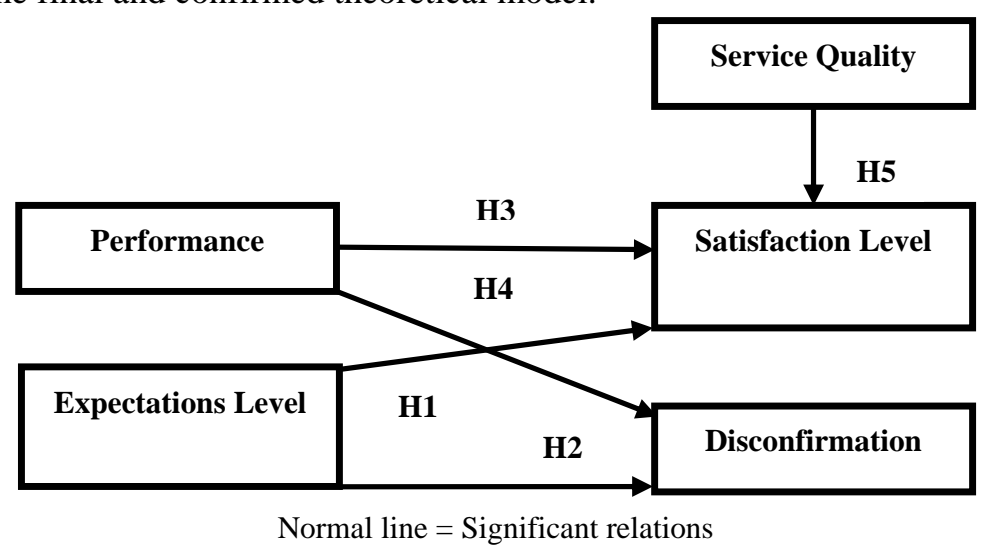

Figure 4. Theoretical model confirmed (Source: author's own calculation). 


\section{Limitations and Future Research Directions}

The limitations of this research are derived from the sample size and the applications of this, as it only refers to a Business School located in the city of Alicante (Spain). This is why, in order for this type of study to have a lot more representation, it should include other schools dedicated to promote graduate programs in the area of business. Future lines of research will follow that line; in other words, it will include more business schools in the sample, and include other demographic variables.

\section{Conclusion}

As it been observed after contrasting hypothesis, we can confirm that consumer expectations are very important in making the process of disconfirmation of these, and their subsequent level of satisfaction obtained. The same is applied in the performance, as this is direct conditioning factor of both disconfirmation and the satisfaction. Finally, as mentioned by the literature, offering quality products and services directly affects the levels of satisfaction that an individual may experience using certain product or service. That is why the completion of such studies can contribute significantly not only to the establishment of methodologies to achieve the quality control of products and services offered by a company, but also to determine whether these in turn reach the goal of meeting the needs of clients and their expectations.

\section{References}

Alves, H., \& Raposo, M. (2004). La medición de la satisfacción en la enseñanza universitaria: el ejemplo de la Universidad Da Beira Interior. Revista Internacional de Marketing Público y no lucrativo, 1(1), 73-88.

Anderson, J. C., \& Gerbing, D. W. (1988). Structural equation modelling in practice: A review and recommended two-step approach. Psychological Bulletin, 103, 411- 423.

Bagozzi, R. P., \& Baumgartner, H. (1994). The evaluation of structural equation models and hypothesis testing. In R. Bagozzi (Ed.), Principles of Marketing Research (pp. 386-422), Cambridge, M.A.: Blackwell Publishers.

Bagozzi, R. P., \& Yi, Y. (1988). On the evaluation of structural equation models. Journal of the Academy of Marketing Science, 16(1), 74-94.

Bello, L., Polo, Y., \& Vázquez, R. (1999). Temas de investigación en Marketing: Incidencia profesional y Académica. Papeles de Economía Española, 78-79, 212-217.

Bentler, P. M. (1989). EQS structural equations program manual. Los Angeles: BMDP Statistical Software.

Bogue, E. G., \& Saunders, K. L. (1992). The evidence for quality. San Francisco: Jossey-Bass.

Bollen, K. (1989). Structural equations with latent variables. New York: John Wiley and Sons.

Brady, M. K., \& Robertson, C. J. (2001). Searching for a consensus on the antecedent role of service quality and satisfaction: An exploratory cross-national study. Journal of Business Research, 51(1), 53-60.

Brown, S. W., \& Swartz, T. A. (1989). A gap analysis of the professional service quality. Journal of Marketing, 53, 92-98.

Calabuig, F. (2005). La calidad percibida en los servicios náuticos de la Generalitat Valenciana (Tesis Doctoral. Universitat de Valencia).

Caruana, A. (2002). Service loyalty. The effects of service quality and the mediating role of customer satisfaction. European Journal of Marketing, 36(7-8), 811-828.

Churchill, G. A. (1979). A paradigm for developing better measures of marketing constructs. Journal of Marketing Research, 16(1), 64-73.

Civera, M. (2008). Análisis de la relación entre calidad y satisfacción en el ámbito hospitalario en función del modelo de gestión establecido (Tesis Doctoral, Universitat Jaume I).

Clow, K. E., Kurtz, D. L., \& Ozment, J. (1998). A longitudinal study of the stability of consumer expectations of services. Journal of Business Research, 42, 63-73.

Cohen, J. B., \& Houston, M. J. (1972). Cognitive consequences of brand loyalty. Journal of Marketing Research, 9, 97-99.

Comité de Motivación de la Calidad. (1987). Programas de Calidad Total: Fundamentos y guía para la implantación. Asociación Española para la Calidad. Madrid. 
Cronbach, L. J. (1951). Coefficient alpha and the internal structure of tests. Psychometrika, 16(3), 297-334.

Cronin, J. J., \& Taylor, S. A. (1992). Measuring service quality: A re-examination and extension. Journal of Marketing, 56, 55-68.

Day, R. L. (1975). Consumer satisfaction/dissatisfaction with services and intangible products. Proceedings of the Markeing Research Seminar. Marseille: Institut d’Ad des Entreprises, Université D’Aix.

Day, R. L. (1977a). Toward a process model of consumer satisfaction. In H. K. Hunt (Ed.), Conceptualisation and measurement of consumer satisfaction and dissatisfaction (pp. 153-186), Cambridge, Mass: Marketing Science Institute (May).

Deighton, J. (1992). The consumption of performance. Journal of Consumer Research, 19(December), 362-372.

Deming, E. (1989). Calidad productividad y competitividad. La salida de la crisis. Editorial Díaz de Santos. Madrid.

Engel, J. F., Kollat, D. T., \& Blackwell, R. D. (1968). Consumer behavior. New York: Holt, Rinehart \& Winston.

Fornell, C., \& Larcker, D. F. (1981). Evaluating structural equations models with unobservable variables and measurement error. Journal of Marketing Research, 18(1), 39-50.

Freed, J. E., \& Klugman, M. R. (1997). Quality principles and practices in higher education. Phoenix, A. Z.: Orxy Press.

Galgano, A. (1993). Calidad total. Editorial Díaz de Santos. Madrid.

Giese, J. L., \& Cote, J. A. (2000). Defining consumer satisfaction. Academy of Marketing Science Review, 1, 1-34.

Grönroos, C. (1982). Strategic management and marketing in the service sector. Helsinki: Swedish School of Economics and Business Administration.

Grönroos, C. (1984). A service quality model and its marketing implications. European Journal of Marketing, 18(4), 36-44.

Grönroos, C. (1994). Marketing y gestión de servicios: la gestión de los momentos de la verdad y la competencia en los servicios. Madrid: Díaz de Santos.

Howard, J. A., \& Sheth, J. N. (1969). The theory of buyer behavior. New York: John Wiley and Sons.

Juran, J. M. (1990a). Juran y el liderazgo para la calidad. Madrid: Díaz de Santos.

Kotler, P. (1982). Marketing for non-profit organizations. Englewood Cliffs: Prentice Hall.

Kotler, P., \& Fox, K. (1985). Strategic marketing for educational institutions. New York: Prentice Hall.

LaTour, S. A., \& Peat, N. C. (1979). Conceptual and methodological issues in consumer satisfaction research. In W. F. Wilkie (Ed.), Advances in consumer research. Ann Arbor, M.I.: Association for Consumer Research, 6, 431-437.

Lee, J., Graefe, A. R., \& Burns, R. C. (2004). Service quality, satisfaction, and behavioral intention among forest visitors. Journal of Travel \& Tourism Marketing, 17(1), 73-82.

Lévy, J. P., \& Varela, J. (2003). Análisis multivariante para las Ciencias Sociales. Madrid: Pearson’s Educación, S. A., Prentice Hall.

Lindahl, C. W. (1995). Measuring the quality of universities. The Chronicle of Higher Education, 3.

López, C., Fernández, K., \& Mariel, P. (2005). La satisfacción del consumidor: una aplicación del análisis factorial confirmatorio a la industria automovilística española. Estadística Española, 47(158), 117-141.

Lovelock, C. (1983). Classifying services to gain strategic marketing insights. Journal of Marketing, 47, 9-20.

Miller, J.A. (1977). Studying satisfaction, modifying models, eliciting expectations, posing problems and making meaninful measurements. In H. K. Hunt (Ed.). Conceptualization and measurement of consumer satisfaction and dissatisfaction (pp. 72-91). Cambridge, M.A.: Marketing Science Institute.

Moliner, B., Berenguer, G., \& Gil, I. (2001). La importancia de la performance y las expectativas en la formación de la satisfacción del consumidor. Investigaciones Europeas de Dirección y Economía de la Empresa, 7(3), 155-172.

Nunnally, J. C. (1978). Psychometric theory. New York: McGraw Hill Book Company.

Olander, F. (1977). Consumer satisfaction-A skeptic's view. In Hunt, H. K. (Ed.). Conceptualization and measurement of consumer satisfaction and dissatisfaction (pp. 409-454). Cambridge, M.A.: Marketing Science Institute.

Oliver, R. L. (1980). A cognitive model of the antecedents and consequences of satisfaction decisions. Journal of Marketing Research, 17, 460-469.

Oliver, R. L. (1981). Measurement and evaluation of satisfaction processes in retail settings. Journal of Retailing, 57(3), 25-48.

Oliver, R. L. (1994). Conceptual Issues in the Structural Analysis of Consumption emotion, satisfaction, and quality: Evidence in a service setting. Advances in Consumer Research, 21, 16-22.

Oliver, R. L. (1997). Satisfaction: A behavioral perspective on the consumer. New York: Mc Graw-Hill.

Olson, J. C., \& Dover, P. A. (1976). Disconfirmation of consumer expectations through product trial. Journal of Applied Psychology, 64, 179-189. 
Oxenfeld, A. R. (1950). Consumer knowledge: Its measurement and extent. Review of Economics and Statistics, 32, 300-314.

Parasuraman, A., Zeithaml, V. A., \& Berry, L. L. (1985). A conceptual model of service quality and its implications for future research. Journal of Marketing, 49, 41-50.

Parasuraman, A., Zeithaml, V. A., \& Berry, L. L. (1988). SERVQUAL: A multiple item scale for measuring consumer perceptions of service quality. Journal of Retailing, 64(1), 12-40.

Parasuraman, A., Zeithaml, V. A., \& Berry, L. L. (1991). Refinement and reassessment of the SERVQUAL scale. Journal of Retailing, 67(4), 420-450.

Patterson, P. G., \& Johnson, L. W. (1995). Focal brand experience and product-Based norms as moderators in the satisfaction formation process. Journal of Consumer Satisfaction, Dissatisfaction and Complaining Behavior, 8, 22-31.

Peterson, R. A., \& Wilson, W. R. (1992). Measuring customer satisfaction: Fact and artifact. Journal of the Academy of Marketing Science, 20(1), 61-71.

Petrick, J. F. (2004). The roles of quality, value, and satisfaction in predicting cruise passengers behavioral intentions. Journal of Travel Research, 42(4), 397-407.

Petrick, J. F., \& Sirakaya, E. (2004). Segmenting cruisers by loyalty. Annals of Tourism Research, 31(2), 472-475.

Reed, R., Lemak, D. J., \& Montgomery, J. C. (1996). Beyond process: TQM content and firm performance. Academy of Management Review, 21(1), 173-202.

Rushton, A., \& Carson, D. (1989). The marketing of services: Managing intangibles. European Journal of Marketing, 23(8), 23-43.

Rust, R. T., \& Oliver, R. L. (1994). Service quality insights and managerial implications from the frontier. In R. T. Rust, \& R. L. Oliver (Eds.), Service quality new directions in theory and practice (pp. 1-19). London: Sage.

San Martín, H. (2005). Estudio de la imagen de destino turístico y el proceso global de satisfacción: adopción de un enfoque integrador. Tesis Doctoral. Universidad de Cantabria.

Santiago, J. (1999). La calidad de servicio bancario: entre la fidelidad y la rupture (Tesis Doctoral, Universidad Complutense de Madrid).

Sanzo, M. J., Del Rio, A. B., Iglesias, V., \& Vazquez, R. (2003). Attitude and satisfaction in a traditional food product. British Food Journal, 105(11), 771-790.

Seto, D. (2003). La influencia de la calidad de servicio, la imagen, la satisfacción y la confianza en la fidelidad del cliente. Revista Española de Investigación de Marketing ESIC, 7(1), 27-55.

Singh, J., \& Howell, R. D. (1985). Consumer complaining behavior: A review and prospectus. In H. K. Hunt, \& R. L. Day (Eds.), Consumer satisfaction, dissatisfaction and complaining behavior (pp. 59-66). Bloomington, I.N.: Indiana University.

Steenkamp, J. B. (1990). Conceptual model of quality perception process. Journal of Business Research, 21, 309-333.

Swan, J. E., \& Trawick, I. F. (1979). Satisfaction related to predictive vs. desired expectations. Refining Concepts and Measures on Consumer Satisfaction and Complaining Behavior. In H. K. Hunt, \& R. L. Day (Eds.), Proceedings of the 1979 Consumer Satisfaction, Dissatisfaction and Complaining Behavior Conference. Bloomington, I.N.: School of Business, Indiana University, 7-12.

Swan, J. E., \& Trawick, I. F. (1981). Disconfirmation of expectations and satisfaction with a retail service. Journal of Retailing, 57(3), 49-67.

Szymanski, D. M., \& Henard, D. H. (2001). Customer satisfaction: A meta—Analysis of the empirical evidence. Journal of the Academy of Marketing Science, 29(1), 16-35.

Taylor, K. A., \& Burns, M. J. (1999). Changes in pre and post-purchase evaluative criteria: Exploring the impact on consumer dissatisfaction. Journal of Consumer Satisfaction Dissatisfaction and Complaining Behavior, 12, 90-99.

Thomas, J. (2001). A methodology for linking customer acquisition to consumer retention. Journal of Marketing Research, 38, 262-268.

Wirtz, J., Mattila, A. S., \& Tan, R. L. (2000). The moderating role of target-Arousal on the impact of affect in satisfaction-An examination in the context of service experiences. Journal of Retailing, 76(3), 347-365.

Yi, Y. (1993). The determinants of consumer satisfaction: the moderating role of ambiguity. Advances in Consumer Research, 20, 502-506.

Yoon, Y., \& Uysal, M. (2005). An examination of the effects of motivation and satisfaction on destination loyalty: A structural model. Tourism Management, 26, 45-56.

Zeithaml, V. (1988). Consumer perceptions of price, quality and value: A means-end model and synthesis of evidence. Journal of Marketing, 52(3), 2-22. 